\title{
PENERAPAN METODE SIMPLE ADDITIVE WEIGHTING UNTUK MENENTUKAN PENGGUNAAN DANA BANTUAN OPERASIONAL SEKOLAH
}

\author{
Puja Irawan $^{1}$, Petrus Sokibi², Ivan Susanto ${ }^{3}$ \\ 1,2,3Program Studi Teknik Informatika, \\ Fakultas Teknologi dan Informasi, Universitas CIC, Cirebon, Indonesia \\ 1'puja.libra16@gmail.com, ${ }^{2}$ petrus.sokibi@cic.ac.id, ${ }^{3}$ susanto_ivan@ $@$ rocketmail.com
}

\begin{abstract}
ABSTRAK
Dana Bantuan Operasional Sekolah (BOS) merupakan salah satu bentuk upaya pemerintah untuk mendukung pendidikan di Indoensia. Dana BOS dapat diterima oleh sekolah dengan mengikuti persyaratan yang berlaku. Penentuan penggunaan dana BOS umunya dilakukan dengan hasil suara terbanyak yang didapatkan ketika rapat penggunaan dana BOS. Hal tersebut dianggap kurang efektif karena tidak jelas keprioritasaanya, sehingga untuk mendapatkan hasil keputusan yang lebih efektif solusinya adalah dengan menggunakaan sebuah sistem untuk menunjang keputusan.Sistem Pendukung Keputusan untuk menentukan penggunaan dana BOS dilakukan dengan menggunakan metode Simple Additive Weighting (SAW). Sistem ini berbasis web yang dibuat dengan memanfaatkan seperangkat komputer yaitu laptop dan menggunakan bahasa pemrograman PHP (Hypertext Preprocessor) serta menggunakan database MySQL. Sistem ini dapat digunakan untuk melakukan pengajuan dan menghitung data pengajuan. Dari hasil perhitungan tersebut Kepala Sekolah dapat memilih pengajuan yang akan disetujui dengan mempertimbangkan hasil perhitungan metode SAW. Sistem ini menghasilkan informasi berupa laporan penggunaan dana BOS yang dapat dilihat oleh guru dan orang tua siswa. Kelebihan dari sistem ini adalah informasi penggunaan dana BOS disertai dengan tingkat keprioritasannya karena sistem ini menerapkan metode SAW untuk menunjang keputusan penentuan penggunaan dana BOS, namun laporan yang dihasilkan hanya sebagai informasi penggunaan dana BOS bukan untuk laporan kepada kementrian pendidikan dan kebudayaan.
\end{abstract}

Kata Kunci: Sistem Pendukung Keputusan, Bantuan Operasional Sekolah, Web.

\begin{abstract}
The School Operational Assistance Fund (BOS) is a form of government effort to support education in Indonesia. Schools can receive BOS funds by following the applicable requirements. The determination of the use of BOS funds is generally made with the highest votes obtained at a meeting on the use of BOS funds. This is considered less effective because the priorities are not clear, so to get a more effective decision result, the solution is to use a system to support decisions. The Decision Support System to determine the use of BOS funds is carried out using the Simple Additive Weighting (SAW) method. This web-based system is made by utilizing a computer, namely a laptop and using the PHP (Hypertext Preprocessor) programming language and using the MySQL database. This system can be used to make submissions and calculate submission data. From the results of these calculations the Principal can choose the application to be approved by considering the results of the SAW method calculation. This system produces information in the form of reports on the use of BOS funds that can be seen by teachers and parents of students. The advantage of this system is that the information on the use of BOS funds is accompanied by a level of priority because this system applies the SAW method to support decisions on the use of BOS funds, however the reports produced are only for information on the use of BOS funds, not for reports to the ministry of education and culture.
\end{abstract}

Keywords: Decision Support Systems, School Operational Assistance, Web. 


\section{PENDAHULUAN}

Salah satu bentuk upaya pemerintah dalam mendukung peningkatan kualitas pendidikan di Indonesia adalah dengan memberikan pendanaan yang signifikan dengan pemanfaatan dana Anggaran Pendapatan dan Belanja Negara (APBN) yaitu Bantuan Operasional Sekolah (BOS). Program BOS ditujukan untuk meringankan peserta didik dalam menempuh pendidikan yang sebelumnya harus membayar iuran Sumbangan Pembinaan Pendidikan (SPP) setiap bulan untuk membiayai operasional sekolah. Penggunaan dana BOS biasanya dilakukan berdasarkan keputusan dari Kepala Sekolah, Dewan Guru, dan Komite Sekolah untuk memutuskan penggunaan dana terhadap suatu kepentingan dengan hasil pemungutan suara dari hasil rapat, hal tersebut dianggap kurang efisien dalam pengambilan keputusan.

SMK Asyifa Depok merupakan salah satu Sekolah Menengah Kejuruan yang bertempat di jalan Kiyani Desa Cikeduk Kecamatan Depok Kabupaten Cirebon. Dalam sekolah tersebut alokasi dana BOS dikelola oleh Tata Usaha dan dengan persetujuan atau ijin dari Kepala Sekolah dan Komite Sekolah. Dengan melimpahkan keputusan atas penggunaan dana BOS hanya kepada Kepala Sekolah dan Komite Sekolah berdasarkan hasil pemungutan suara dalam rapat dianggap kurang efisien, dimana penentuan penggunaan dana BOS hanya didasarkan pada suara terbanyak dari jumlah peserta rapat yang hadir. Terlebih lagi keputusan mengenai penggunaan dana BOS tidak disertai dengan penjelasan keprioritasannya, sehingga menimbulkan pro dan kontra guru-guru terhadap keputusan yang ditetapkan karena tidak semua guru pro terhadap keputusan yang ditetapkan. Sebagai contoh adalah ketika ada salah satu atau sebagian guru yang kontra atau kurang menyetujui keputusan yang ditetapkan, maka tidak akan bisa menyalurkan aspirasinya dan tidak mendapatkan kejelasan mengenai alasan pengambilan keputusan sehingga hanya bisa menerima keputusan tersebut. Dalam sekolah tersebut juga tidak memberikan informasi mengenai penggunaan dana BOS kepada orang tua siswa, sehingga orang tua siswa tidak ikut serta dalam mengawasi penggunaan dana BOS pada sekolah tersebut.

Sistem Pendukung Keputusan Rehabilitasi yang menentukan urutan prioritas rehabilitasi bangunan SDN/MIN di Kabupaten Pulang Pisau sudah mendapatkan hasil maksimal dengan menggunakan metode Analytical Hierarchy Process dapat memberikan hasil dengan akurasi sebesar $100 \%$ [1].

Metode Simple Additive Weighting (SAW) dapat diimplementasikan pada Sistem Pendukung Keputusan seleksi pengguna jasa leasing. Pembobotan yang diterapkan pada sistem pendukung keputusan tersebut menggunakan pembobotan Rank Order Centroid (ROC). Dengan menggunakan metode Simple Additive Weighting (SAW) dan pembobotan Rank Order Centroid (ROC) dapat memberikan hasil yang cukup memuaskan yaitu menghasilkan keakuratan sebesar 95,7\% [2]. Penggunaan Metode Simple Additive Weighting (SAW) dalam menentukan kualitas pembelajaran guru dianggap cukup memuaskan, karena dengan menggunakan metode tersebut dapat memberikan analisis proses pembelajaran guru-guru SD Inpres Perumnas Antang 1 dan memberikan hasil berupa nama guru-guru yang memiliki kualitas baik dalam pembelajaran dengan tingkat akurasi sebesar 96\% [3].

Berdasarkan permasalahan yang terjadi di SMK Asyifa Depok serta belum adanya penerapan metode SAW dalam menunjang keputusan penentuan penggunaan dana BOS maka penulis tertarik untuk membuat sistem dengan judul "Penerapan Metode Simple Additive Weighting untuk Menentukan Penggunaan Dana Bantuan Operasional Sekolah" yang bertujuan untuk membantu menunjang pengambilan keputusan penggunaan dana BOS, memberikan informasi penggunaan dana BOS kepada guruguru dengan disertai tingkat keprioritasan dari keputusan yang diambil, memberikan informasi mengenai penggunaan dana BOS kepada orang tua siswa sehingga dapat ikut serta mengawasi penggunaan dana BOS, dan mengimplementasikan metode SAW pada Sistem Informasi Penggunaan Dana BOS. Penggunaan metode SAW pada penilitian ini ditujukan untuk memberikan hasil keputusan yang optimal berdasarkan nilai bobot yang dihasilkan dari perhitungan matriks yang dilakukan berdasarkan kriteria yang telah ditentukan.

\section{TINJAUAN PUSTAKA}

\subsection{Sistem Pendukung Keputusan}

Sistem pendukung keputusan merupakan sistem informasi yang bersifat interaktif dan menyediakan informasi, pemodelan serta manipulasi data yang digunakan untuk membantu mengambil keputusan dalam situasi semi terstruktur maupun tidak terstruktur [4].

\subsection{Simple Additive Weighting}

Metode Simple Additive Weighting (SAW) adalah salah satu metode sistem pendukung keputusan yang memiliki konsep dasar untuk mencari penjumlahan terbobot dari rating kinerja pada setiap alternatif pada semua atribut. Kelebihan dari metode SAW dengan metode sistem pendukung keputusan yang lain adalah metode ini memiliki kemampuan untuk melalukan penilaian secara lebih tepat karena didasarkan pada nilai kriteria dan bobot preferensi yang telah ditentukan, selain itu metode ini juga dapat menyeleksi alternatif terbaik dari sejumlah alternatif yang ada karena adanya proses perangkingan setelah menentukan bobot pada setiap atribut [2].

Langkah-langkah penyelesaian masalah menggunakan metode Simple Additive Weighting yaitu [5]:

1) Menentukan kriteria yang akan dijadikan acuan dalam pengambilan keputusan, yaitu Ci.

2) Memberikan bobot pada masing-masing kriteria (W).

3) Memberikan rating keocockan setiap alternatif pada setiap kriteria kemudian memodelkannya ke dalam bilangan fuzzy yang kemudian akan dikonversikan ke bilangan Crips.

4) Membuat matriks keputusan berdasarkan kriteria (Ci), kemudian melakukan normalisasi matriks berdasarkan persamaan yang disesuaikan dengan jenis atribut 
(atribut keuntungan atau atribut biaya) sehingga diperoleh matriks ternormalisasi (R).

$$
\begin{array}{cc}
R_{\mathrm{ij}}=\frac{X_{i j}}{\operatorname{Max}_{i} X_{i j}} & \text { Jika } \mathrm{J} \text { adalah atribut Benefit. } \\
R_{\mathrm{ij}}=\frac{\operatorname{Min} X_{i j}}{X_{i j}} & \text { Jika } \mathrm{J} \text { adalah atribut } \text { Cost. }
\end{array}
$$

Keterangan setiap kriteria:

$\mathrm{R}_{\mathrm{ij}} \quad$ : Nilai rating kinerja ternormalisasi.

$\mathrm{R}_{\mathrm{ij}} \quad$ : Nilai atribut yang dimiliki dari.

$\operatorname{Max} X_{i j}$ : Nilai terbesar dari setiap kriteria.

Min $X_{i j}$ : Nilai terkecil dari setiap kriteria.

Benefit : Jika nilai terbesar adalah terbaik.

Cost : Jika nilai terkecil adalah terbaik.

5) Hasil akhir diperoleh dari proses perangkingan yaitu penjumlahan dan perkalian matriks ternomalisasi $(\mathrm{R})$ dengan vektor bobot sehingga diperoleh nilai terbesar yang dipilih sebagai alternatif terbaik (Ai) sebagai solusi.

$$
V_{\mathrm{i}}=\sum_{j=1}^{n} W_{j} R_{i j}
$$

Keterangan setiap kriteria:

$$
\begin{array}{ll}
\mathrm{V}_{\mathrm{i}} & \text { : Ranking untuk setiap alternatif } \\
\mathrm{W}_{\mathrm{j}} & \text { : Nilai atribut yang dimiliki dari. }
\end{array}
$$

\subsection{Bantuan Operasional Sekolah}

Program Bantuan Operasional Sekolah merupakan bentuk bantuan yang diberikan pemerintah untuk membiayai operasional sekolah agar tidak dibebankan kepada siswa, biaya tersebut diberikan pada sekolahsekolah tingkat Sekolah Dasar dan Sekolah Menengah Pertama [6].

\section{METODOLOGI PENELITIAN}

\subsection{Perancangan Sistem}

Perancangan sistem ini digambarkan dengan use case diagram yang terdiri dari 4 user, diantaranya:

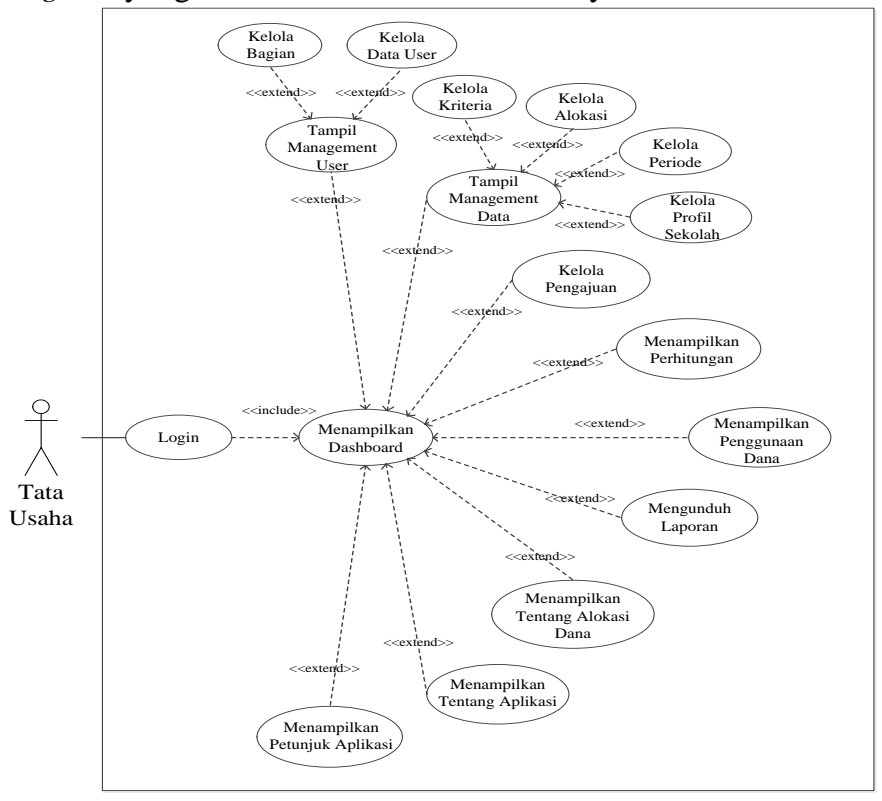

Gambar 1. Use Case Diagram Tata Usaha

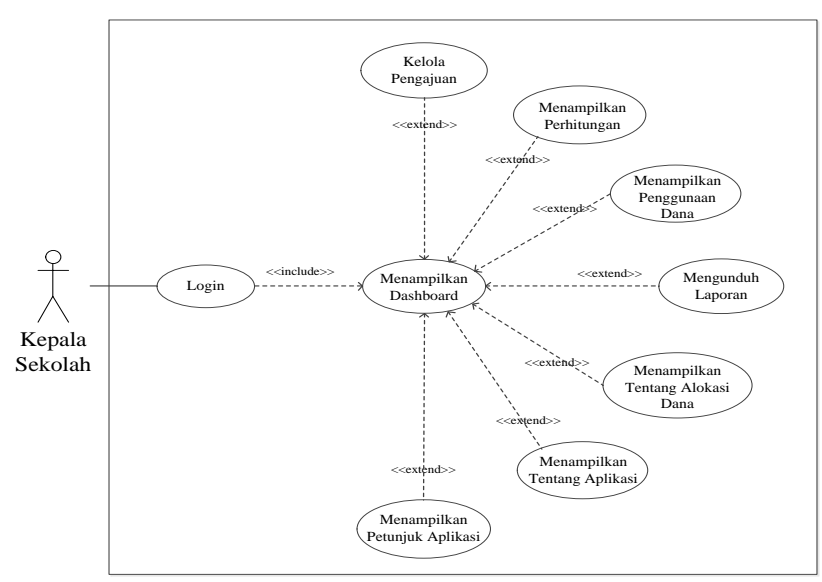

Gambar 2. Use Case Diagram Kepala Sekolah

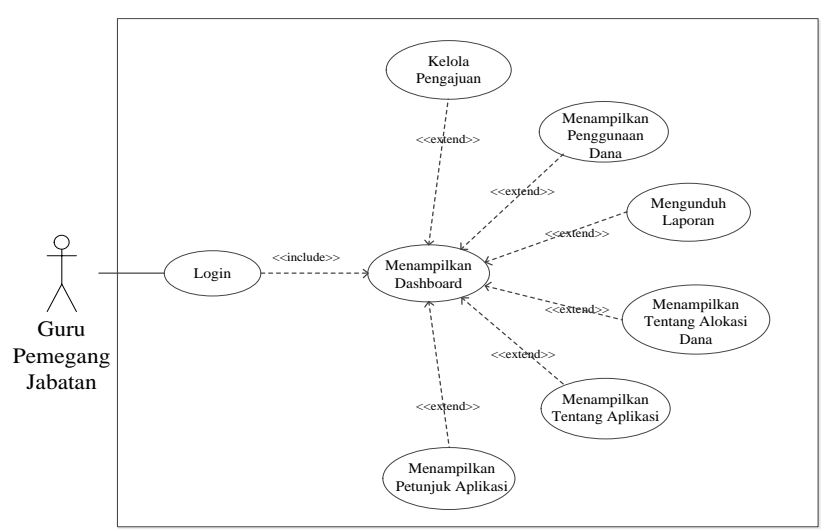

Gambar 3. Use Case Diagram Guru Pemegang Jabatan

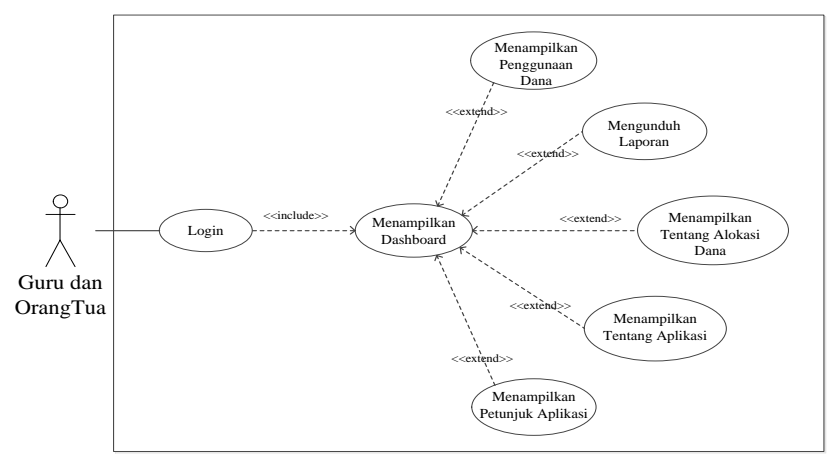

Gambar 4. Use Case Diagram Guru dan Orang Tua

\subsection{Simulasi Perhitungan}

Langkah-langkah metode SAW adalah sebagai berikut:

1) Menentukan Kriteria (Ci)

Pada tahapan ini dilakukan penentuan kriteria. Adapun kriteria pada sistem ini meliputi:

Tabel 1. Kriteria

\begin{tabular}{cl}
\hline Kode Kriteria $\left(\mathbf{C}_{\mathbf{i}}\right)$ & \multicolumn{1}{c}{ Kriteria } \\
\hline $\mathrm{C}_{1}$ & Jenis Pemanfaatan \\
$\mathrm{C}_{2}$ & Tingkat Kebutuhan \\
$\mathrm{C}_{3}$ & Waktu Pengajuan \\
$\mathrm{C}_{4}$ & Dana yang Diajukan \\
\hline
\end{tabular}


2) Memberikan Nilai Bobot $(\mathbf{W})$

Pada tahapan ini dilakukan penentuan bobot pada setiap kriteria. Adapun bobot kriteria meliputi:

Tabel 2. Nilai Bobot

\begin{tabular}{clc}
\hline$\left(\mathbf{C}_{\mathbf{i}}\right)$ & \multicolumn{1}{c}{ Kriteria } & Bobot \\
\hline $\mathrm{C}_{1}$ & Jenis Pemanfaatan & $40 \%$ \\
$\mathrm{C}_{2}$ & Tingkat Kebutuhan & $20 \%$ \\
$\mathrm{C}_{3}$ & Waktu Pengajuan & $20 \%$ \\
$\mathrm{C}_{4}$ & Dana yang Diajukan & $20 \%$ \\
\hline
\end{tabular}

3) Memberikan Rating Kecocokan

Pada tahapan ini memberikan rating kecocokan pada alternatif setiap kriteria. Adapun nilai-nilai pada parameter penelian setiap kriteria mepiputi:

Tabel 3. Nilai Jenis Pemanfaatan

\begin{tabular}{lc}
\multicolumn{1}{c}{ Jenis Pemanfaatan } & Nilai \\
\hline Perbaikan & 3 \\
Pembiayaan atau Pembayaran & 2 \\
Pembelian & 1 \\
\hline
\end{tabular}

Tabel 4. Nilai Tingkat Kebutuhan

\begin{tabular}{lc}
\hline \multicolumn{1}{c}{ Tingkat Kebutuhan } & Nilai \\
\hline Sangat Dibutuhkan & 4 \\
Dibutuhkan & 3 \\
Cukup Dibutuhkan & 2 \\
Kurang Dibutuhkan & 1 \\
\hline
\end{tabular}

Tabel 5. Nilai Waktu Pengajuan

\begin{tabular}{ccc}
\hline Bulan & Waktu Pengajuan & Nilai \\
\hline Januari & Bulan Pertama & 3 \\
Februari & Bulan Kedua & 2,5 \\
Maret & Bulan Ketiga & 2 \\
April & Bulan Pertama & 3 \\
Mei & Bulan Kedua & 2,5 \\
Juni & Bulan Ketiga & 2 \\
Juli & Bulan Keempat & 1,5 \\
Agustus & Bulan Kelima & 1 \\
September & Bulan Keenam & 0,5 \\
Oktober & Bulan Pertama & 3 \\
November & Bulan Kedua & 2,5 \\
Desember & Bulan Ketiga & 2 \\
\hline
\end{tabular}

Tabel 6. Nilai Dana yang Diajukan

\begin{tabular}{cc}
\hline Dana & Nilai \\
\hline Kurang dari 1000000 & 0,5 \\
Lebih dari 1000000 dan kurang dari 2000000 & 1 \\
Lebih dari 2000000 dan kurang dari 3000000 & 1,5 \\
Lebih dari 3000000 dan kurang dari 4000000 & 2
\end{tabular}

Setelah mengetahui parameter penilaian maka data dirubah menjadi nilai seperti yang terlihat pada tabel 7.

Tabel 7. Rating Kecocokan

\begin{tabular}{ccccc}
\hline$\left(\mathbf{A}_{\mathbf{i}}\right)$ & $\left(\mathbf{C}_{\mathbf{1}}\right)$ & $\left(\mathbf{C}_{2}\right)$ & $\mathbf{( \mathbf { C } _ { 3 } )}$ & $\mathbf{( \mathbf { C } _ { 4 } )}$ \\
\hline $\mathrm{A}_{1}$ & 2 & 4 & 3 & 0,5 \\
$\mathrm{~A}_{2}$ & 2 & 4 & 3 & 1,5 \\
$\mathrm{~A}_{3}$ & 2 & 4 & 3 & 0,5 \\
$\mathrm{~A}_{4}$ & 2 & 4 & 3 & 0,5 \\
$\mathrm{~A}_{5}$ & 3 & 4 & 3 & 2,5 \\
$\mathrm{~A}_{6}$ & 2 & 1 & 3 & 0,5 \\
$\mathrm{~A}_{7}$ & 2 & 1 & 3 & 1,5 \\
$\mathrm{~A}_{8}$ & 2 & 4 & 3 & 3 \\
$\mathrm{~A}_{9}$ & 2 & 4 & 3 & 0,5 \\
$\mathrm{~A}_{10}$ & 2 & 4 & 3 & 0,5 \\
\hline
\end{tabular}

4) Membuat Matriks Keputusan (Normalisasi)

Pada tahap ini melakukan proses normalisasi berdasarkan sifat dari kriteria, baik berupa atribut keuntungan maupun atribut biaya. Adapun Proses Normalisasi sebagai berikut:

1. Kriteria Jenis Pemanfaatan

Kriteria Jenis Pemanfaatan bersifat benefit sehingga nilai pada kolom $\mathrm{C}_{1}$ akan dibagi dengan nilai maksimal pada kolom $\mathrm{C}_{1}$ seperti yang terlihat pada tabel 7 nilai maksimal kolom $\mathrm{C}_{1}$ bernilai 3 , maka:

$$
\begin{aligned}
& \mathrm{R} 11=\frac{2}{3}=0,67 \\
& \mathrm{R} 12=\frac{2}{3}=0,67
\end{aligned}
$$

2. Kriteria Tingkat Kebutuhan

Kriteria Tingkat Kebutuhan bersifat benefit sehingga nilai pada kolom $\mathrm{C}_{2}$ akan dibagi dengan nilai maksimal pada kolom $\mathrm{C}_{2}$ seperti yang terlihat pada tabel 7 nilai maksimal kolom $\mathrm{C}_{2}$ bernilai 4 , maka:

$$
\begin{aligned}
& \mathrm{R} 21=\frac{4}{4}=1,00 \\
& \mathrm{R} 22=\frac{4}{4}=1,00
\end{aligned}
$$

3. Kriteria Waktu Pengajuan

Kriteria Tingkat Kebutuhan bersifat cost sehingga nilai minimal pada kolom $\mathrm{C}_{3}$ akan dibagi dengan nilai kolom $\mathrm{C}_{3}$ seperti yang terlihat pada tabel 7 nilai minimal kolom $\mathrm{C}_{3}$ bernilai 3 , maka:

$$
\begin{aligned}
& \mathrm{R} 31=\frac{3}{3}=1,00 \\
& \mathrm{R} 32=\frac{3}{3}=1,00
\end{aligned}
$$

4. Kriteria Dana yang Diajukan

Kriteria Tingkat Kebutuhan bersifat cost sehingga nilai minimal pada kolom $\mathrm{C}_{4}$ akan dibagi dengan nilai kolom $\mathrm{C}_{4}$ seperti yang terlihat pada tabel 7 nilai minimal kolom $\mathrm{C}_{4}$ bernilai 0,5 , maka: 


$$
\begin{aligned}
& \mathrm{R} 41=\frac{0,5}{0,5}=1 \\
& \mathrm{R} 42=\frac{0,5}{1,5}=0,33
\end{aligned}
$$

\begin{tabular}{llllll}
$\mathrm{A}_{10}$ & 0,267 & 0,200 & 0,200 & 0,200 & 0,867 \\
\hline
\end{tabular}

Tabel 8. Matriks Keputusan atau Normalisasi (R)

\begin{tabular}{ccccc}
\hline $\left.\mathbf{A}_{\mathbf{i}}\right)$ & $\left(\mathbf{C}_{\mathbf{1}}\right)$ & $\left.\mathbf{( C}_{\mathbf{2}}\right)$ & $\left.\mathbf{( C}_{\mathbf{3}}\right)$ & $\left.\mathbf{( C}_{\mathbf{4}}\right)$ \\
\hline $\mathrm{A}_{1}$ & 0,67 & 1,00 & 1,00 & 1,00 \\
$\mathrm{~A}_{2}$ & 0,67 & 1,00 & 1,00 & 0,33 \\
$\mathrm{~A}_{3}$ & 0,67 & 1,00 & 1,00 & 1,00 \\
$\mathrm{~A}_{4}$ & 0,67 & 1,00 & 1,00 & 1,00 \\
$\mathrm{~A}_{5}$ & 1,00 & 1,00 & 1,00 & 0,20 \\
$\mathrm{~A}_{6}$ & 0,67 & 0,25 & 1,00 & 1,00 \\
$\mathrm{~A}_{7}$ & 0,67 & 0,25 & 1,00 & 0,33 \\
$\mathrm{~A}_{8}$ & 0,67 & 1,00 & 1,00 & 0,17 \\
$\mathrm{~A}_{9}$ & 0,67 & 1,00 & 1,00 & 1,00 \\
$\mathrm{~A}_{10}$ & 0,67 & 1,00 & 1,00 & 1,00 \\
\hline
\end{tabular}

\section{5) Hasil Akhir}

Pada tahap ini menghitung perkalian nilai bobot dengan alternatif kriteria sehingga menghasilkan hasil sebagai berikut:

$\mathrm{V} 1=(0,4 * 0,67)+(0,2 * 1,00)+(0,2 * 1,00)+(0,2 * 1,00)$

$$
=0,867
$$

$\mathrm{V} 2=(0,4 * 0,67)+(0,2 * 1,00)+(0,2 * 1,00)+(0,2 * 0,33)$ $=0,733$

$\mathrm{V} 3=(0,4 * 0,67)+(0,2 * 1,00)+(0,2 * 1,00)+(0,2 * 1,00)$ $=0,867$

$\mathrm{V} 4=(0,4 * 0,67)+(0,2 * 1,00)+(0,2 * 1,00)+(0,2 * 1,00)$ $=0,867$

V5 $=(0,4 * 1,00)+(0,2 * 1,00)+(0,2 * 1,00)+(0,2 * 0,20)$ $=0,840$

$\mathrm{V} 6=(0,4 * 0,67)+(0,2 * 0,25)+(0,2 * 1,00)+(0,2 * 1,00)$ $=0,717$

V7 $=(0,4 * 0,67)+(0,2 * 0,25)+(0,2 * 1,00)+(0,2 * 0,33)$ $=0,583$

$\mathrm{V} 8=(0,4 * 0,67)+(0,2 * 1,00)+(0,2 * 1,00)+(0,2 * 0,17)$ $=0,700$

V9 $=(0,4 * 0,67)+(0,2 * 1,00)+(0,2 * 1,00)+(0,2 * 1,00)$ $=0,867$

$\mathrm{V} 10=(0,4 * 0,67)+(0,2 * 1,00)+(0,2 * 1,00)+(0,2 * 1,00)$ $=0,867$

Tabel 9. Hasil Perkalian Nilai Bobot

\begin{tabular}{cccccc}
\hline $\left.\mathbf{A}_{\mathbf{i}}\right)$ & $\left(\mathbf{C}_{\mathbf{1}}\right)$ & $\left.\mathbf{( C}_{\mathbf{2}}\right)$ & $\left(\mathbf{C}_{\mathbf{3}}\right)$ & $\mathbf{( \mathbf { C } _ { 4 } )}$ & Hasil \\
\hline $\mathrm{A}_{1}$ & 0,267 & 0,200 & 0,200 & 0,200 & 0,867 \\
$\mathrm{~A}_{2}$ & 0,267 & 0,200 & 0,200 & 0,067 & 0,733 \\
$\mathrm{~A}_{3}$ & 0,267 & 0,200 & 0,200 & 0,200 & 0,867 \\
$\mathrm{~A}_{4}$ & 0,267 & 0,200 & 0,200 & 0,200 & 0,867 \\
$\mathrm{~A}_{5}$ & 0,400 & 0,200 & 0,200 & 0,040 & 0,840 \\
$\mathrm{~A}_{6}$ & 0,267 & 0,050 & 0,200 & 0,200 & 0,717 \\
$\mathrm{~A}_{7}$ & 0,267 & 0,050 & 0,200 & 0,067 & 0,583 \\
$\mathrm{~A}_{8}$ & 0,267 & 0,200 & 0,200 & 0,033 & 0,700 \\
$\mathrm{~A}_{9}$ & 0,267 & 0,200 & 0,200 & 0,200 & 0,867
\end{tabular}

\begin{tabular}{|c|c|c|c|}
\hline$\left(A_{i}\right)$ & Alokasi & Hasil & Perankingan \\
\hline $\mathrm{A}_{1}$ & $\begin{array}{c}\text { Administrasi kegiatan } \\
\text { sekolah }\end{array}$ & 0,867 & 1 \\
\hline $\mathrm{A}_{3}$ & Langganan daya dan jasa & 0,867 & 2 \\
\hline $\mathrm{A}_{4}$ & Langganan daya dan jasa & 0,867 & 3 \\
\hline $\mathrm{A}_{9}$ & $\begin{array}{c}\text { Administrasi kegiatan } \\
\text { sekolah }\end{array}$ & 0,867 & 4 \\
\hline $\mathrm{A}_{5}$ & $\begin{array}{c}\text { Pemeliharaan sarana dan } \\
\text { prasarana Sekolah } \\
\text { Administrasi kegiatan }\end{array}$ & 0,84 & 5 \\
\hline $\mathrm{A}_{2}$ & $\begin{array}{c}\text { sekolah } \\
\text { Kegiatan pembelajaran dan }\end{array}$ & 0,733 & 6 \\
\hline $\mathrm{A}_{6}$ & ekstrakurikuler & 0,717 & 7 \\
\hline $\mathrm{A}_{8}$ & Pembayaran honor & 0,7 & 8 \\
\hline $\mathrm{A}_{7}$ & $\begin{array}{c}\text { Pengembangan profesi guru } \\
\text { dan tenaga kependidikan } \\
\text { Administrasi kegiatan }\end{array}$ & 0,583 & 9 \\
\hline $\mathrm{A}_{10}$ & sekolah & 0,2 & 10 \\
\hline
\end{tabular}

\section{HASIL PENELITIAN}

Implementasi tampilan sistem meliputi:

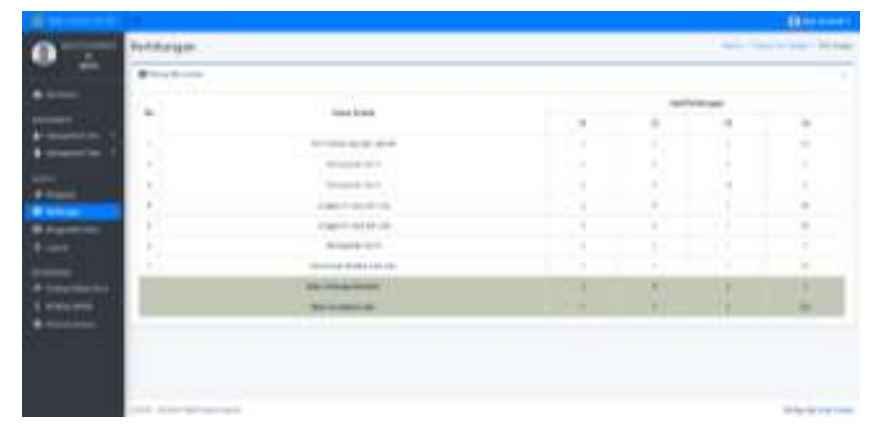

Gambar 5. Tampilan Perhitungan (Rating Kecocokan)

Gambar 5 merupakan tampilan perhitungan (rating kecocokan). Pada halaman tersebut menampilkan data alokasi setelah melakukan rating kecocokan. 


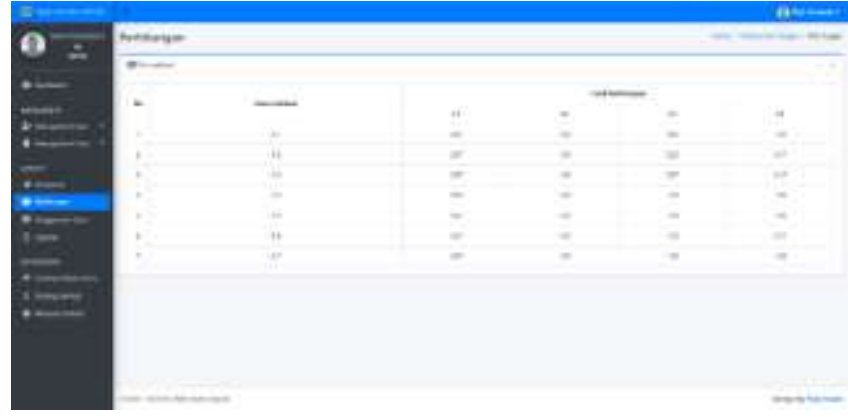

Gambar 6. Tampilan Perhitungan (Normalisasi)

Gambar 6 merupakan tampilan perhitungan (normalisasi). Pada halaman tersebut menampilkan data alokasi setelah melakukan normalisasi.

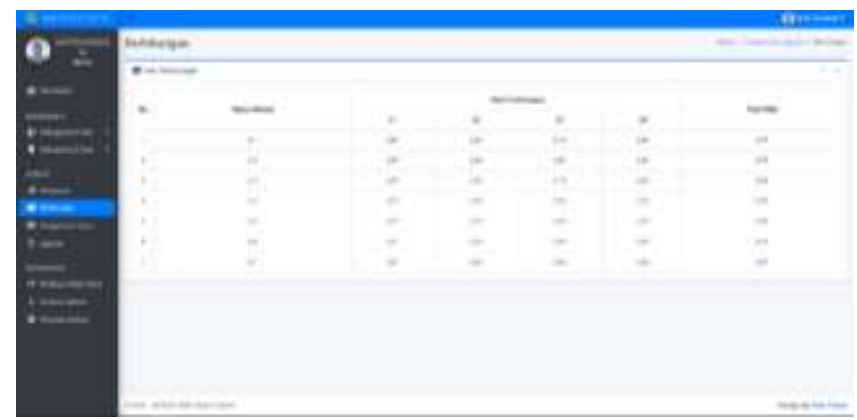

Gambar 7. Tampilan Perhitungan (Hasil Perhitungan)

Gambar 7 merupakan tampilan perhitungan (hasil perhitungan). Pada halaman tersebut menampilkan data alokasi dengan hasil perhitungannya.

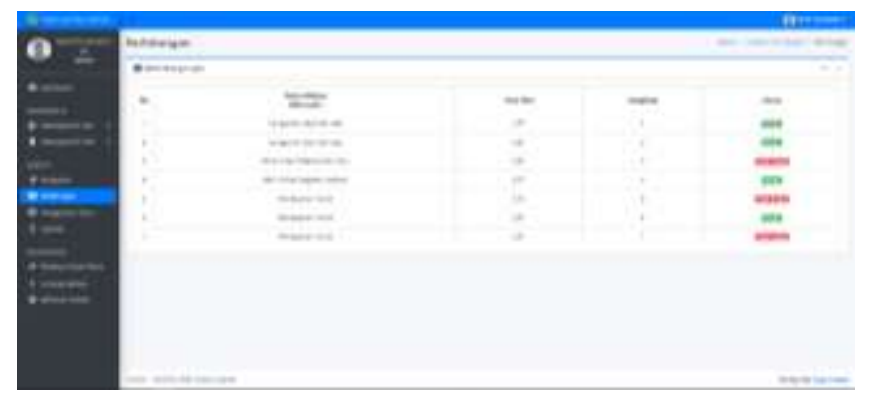

Gambar 8. Tampilan Perhitungan (Tabel Perangkingan)

Gambar 8 merupakan tampilan perhitungan (tabel perangkingan). Pada halaman tersebut menampilkan data alokasi berdasarkan hasil perangkingan.

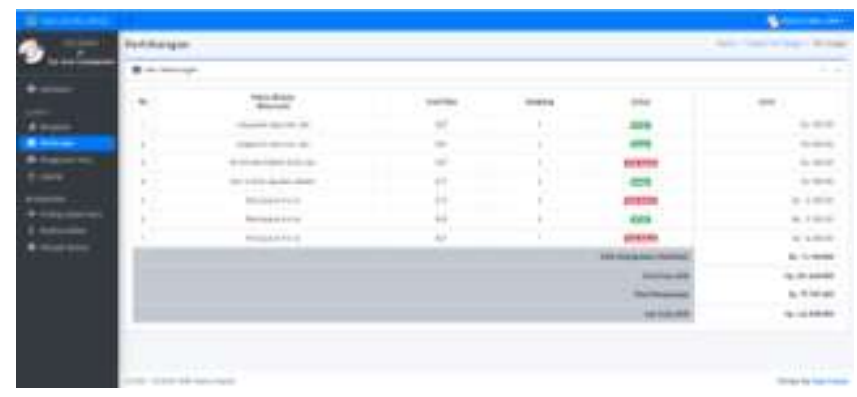

Gambar 9. Tampilan Perhitungan (Hasil Perhitungan)
Gambar 9 merupakan tampilan perhitungan (hasil perhitungan) Kepala Sekolah. Pada halaman tersebut menampilkan data alokasi berdasarkan hasil perangkingan serta dapat melakukan persetujuan pengajuan penggunaan dana BOS dengan mempertimbangkan hasil perhitungan metode SAW.

\section{KESIMPULAN DAN SARAN}

\subsection{Kesimpulan}

Berdasarkan masalah dan pembahasan analisis yang telah diuraikan oleh penulis maka dapat diambil kesimpulan terhadap sistem informasi penggunaan dana BOS adalah:

1) Penentuan penggunaan dana BOS dapat lebih efektif.

2) Sistem informasi penggunaan dana BOS ini dapat memberikan informasi penggunaan dana BOS kepada guru-guru dengan disertai tingkat keprioritasannya.

3) Sistem informasi penggunaan dana BOS ini dapat memberikan informasi kepada orang tua siswa sehingga dapat ikut serta mengawasi penggunaan dana BOS.

4) Penerapan metode SAW pada sistem ini dapat menunjang dalam pengambilan keputusan penggunaan dana BOS.

\subsection{Saran}

Adapun saran-saran yang penulis berikan untuk pengembangan aplikasi ini selanjutnya adalah:

1) Pengembangan pembuatan laporan sehingga laporan yang dihasilkan oleh sistem dapat digunakan untuk laporan kepada kementrian pendidikan dan kebudayaan.

2) Pemilihan alokasi dalam pengajuan penggunaan dana BOS dapat disesuaikan dengan kepentingan yang bersangkutan, sehingga pengajuan dapat dilakukan oleh bagian yang berkepentingan.

3) Pengembangan sistem dengan kriteria yang dinamis.

\section{DAFTAR PUSTAKA}

[1] M. Prasetia., 2019, Sistem Pendukung Keputusan Prioritas Rehabilitasi Bangunan SDN/MIN Di Kabupaten Pulang Pisau, Jurnal Teknologi Berkelanjutan, vol. 8, no. 2, pp. 41-49.

[2] R.T. Utami, D. Andreswari, dan Y. Setiawan., 2016, Implementasi Metode Simple Additive Weighting (SAW) Dengan Pembobotan Rank Order Centroid (ROC) Dalam Pengambilan Keputusan Untuk Seleksi Pengguna Jasa Leasing Mobil, Jurnal Rekursif, vol. 4, no. 2 .

[3] I. Samsie, K. Mujahid, dan R.R. Lembang., 2017, Penentuan Kualitas Pembelajaran Guru Sekolah Dasar Menggunakan Metode Simple Additive Weighting (SAW), Jurnal Pekommas, vol. 2, no. 1, pp. 17-28.

[4] P. Sokibi dan N. Bahiyah., 2018, Perancangan Sistem Kepuasan Masyarakat Terhadap Pelayanan Publik Dengan Metode Analytical Hierarchy Process (AHP), Information Technology Engineering Journals, vol. 3, no. 1, pp. 17-35. 
[5] A. Setiadi, Yunita, A.R. Ningsih., 2018, Penerapan Metode Simple Additive Weighting(SAW) Untuk Pemilihan Siswa Terbaik, Jurnal Sistem Informasi dan Komputer, vol. 07, no. 02, pp. 104-109.

[6] A. Amborowati dan R. Marco., 2016, Analisis Pengelolaan Dan Monitoring Dana Bantuan
Informasi Berbasis Website Pada SLTP Di Daerah Istimewa Yogyakarta, Jurnal Ilmiah DASI, vol. 17, no. 1, pp. 6-14. 